\title{
Effects of nitrogen fertilization on global xylem transcript profiling of Eucalyptus urophylla $x$ grandis evaluated by RNA-seq technology
}

\author{
Eduardo Camargo ${ }^{1 *}$, Leandro Costa ${ }^{1}$, Marçal Soler ${ }^{2}$, Marcela Salazar $^{1}$, Jorge Lepikson', Danieli Gonçalves', \\ Wesley Marques ${ }^{1}$, Marcelo Carazzolle', Yves Martinez ${ }^{3}$, Jacqueline Grima-Pettenati ${ }^{2}$, Gonçalo Pereira ${ }^{1}$ \\ From IUFRO Tree Biotechnology Conference 2011: From Genomes to Integration and Delivery \\ Arraial d'Ajuda, Bahia, Brazil. 26 June - 2 July 2011
}

\section{Background}

Eucalyptus species are the most widely planted hardwood trees in the world representing more than 4.75 million ha in Brazil. Their high productivity, valuable wood properties and wide adaptability could allow sustainable and cost-efficient production of lignocellulosic bioenergy. The main limitation to this objective is wood recalcitrance to degradation which is linked to the structure and composition of lignified secondary cell walls. Lignin, for example, impairs the accessibility of cellulose during kraft pulping as well as during saccharification, a key step of bioethanol production.

The application of nitrogen fertilizers is one strategy to increase growth rates and productivity since nitrogen is one of the most limiting nutrient for tree growth and carbon sequestration. However, the effects of nitrogen availability on wood properties and related gene expression are poorly understood.

In poplar, it was recently reported that $\mathrm{N}$ fertilization increased aerial biomass, while in wood, fibre morphology and secondary cell wall structure and composition were modified. An increase in cellulose coupled with a decrease in lignin was observed and the mRNA profiles evaluated by microarray showed that nitrogen and tension wood have overlapping effects [1]. Moreover, a highly significant genetic correlation was observed between plant growth and lignin/cellulose composition. Quantitative trait loci co-localization identified the genomic position of potential pleiotropic regulators [2].

\footnotetext{
* Correspondence: lealcamargo@gmail.com

'Laboratório de Genômica e Expressão, IB, UNICAMP, Campinas, São Paulo, Brazil

Full list of author information is available at the end of the article
}

In order to get an insight on the regulation of nitrogen availability on wood formation in Eucalyptus, we have studied the effects of nitrogen fertilization on xylem transcriptome profiles using RNA-seq technology.

\section{Methods}

An experimental system was set up in which rooted cuttings of Eucalyptus urophylla $\mathrm{x}$ grandis were fertilized during 30 days with three different amounts of $\mathrm{N}$ (limiting, $-\mathrm{N}$; adequate, $\mathrm{CT}$; excess, $+\mathrm{N}$ ). For the treatment with excess of $\mathrm{N}$ fertilization, we used two different nutrient solutions with different concentration of $\mathrm{NO}_{3}{ }^{-}$ and $\mathrm{NH}_{4}{ }^{+}$.

Histochemical analyses were performed on stem transverse sections $(80 \mu \mathrm{m}$ thick) obtained using a Vibratome (LEICA VT 1000S). The Weisner reagent (phloroglucinol- $\mathrm{HCl}$ ) was used in order to detect lignified cell walls, and calcofluor reagent to evaluate the cellulose content by fluorescence. The samples were observed in confocal microscopy (SP2-AOBS, Leica) and under bright-field microscopy (DM IRBE, Leica) coupled with a CCD camera (DFC 300 FX, Leica).

The construction of the RNA-seq libraries and sequencing were performed accordingly to Illumina's protocols. Prior to analyze the RNA-seq data, we have done an assembly of Eucalyptus ESTs (GENOLYPTUS and NCBI). The 53,412 unigenes produced were automatically annotated using BLAST (e-value cutoff of 1e-5) against different sequence databases.

The RNA-seq reads were aligned against the assembled unigenes using the SOAP2 aligner [3] configured to allow up two mismatches, discard sequences with "N"s and return all optimal alignments. In order to perform the differential expression analysis between 
libraries, a normalization and statistics pipeline were applied using DEG-seq software [4] considering 99\% of confidence rate (cut-off value of 0.01 ).

\section{Results and discussion}

The intensity of staining with phloroglucinol was higher in stem sections from samples grown under - $\mathrm{N}$ treatment as compared to control, whereas it was lower in both $+\mathrm{N}$ treatments. This suggests that lignin biosynthesis is decreased in presence of excess of nitrogen fertilizer. We could also observe in the $+\mathrm{N}$ samples, an increase in cellulose staining intensity with the calcofluor reagent specially noticeable when comparing with $-\mathrm{N}$ samples suggesting that nitrogen also influence cellulose biosynthesis.

The RNA-seq analysis generated 123,121,154 sequence reads after filtering. Of the total reads, about 86 millions matched either to a unique $(47,9 \%)$ or to multiple $(21,8 \%)$ EST locations. Each nitrogen treatment was represented by at least 28.8 million reads, a tag density sufficient for quantitative analysis of gene expression.

The sequence reads were aligned on the new Eucalyptus EST assembly resulting in 36,125 unigenes expressed (15,293 contigs and 20,832 singlets). After statistics analysis, we determined 14,400 differentially expressed genes, that for a preliminary analysis were divided in two scenarios: the genes down-regulated in $-\mathrm{N}$ and upregulated in both $+\mathrm{N}$ treatments (8,967 genes), and the genes up-regulated in $-\mathrm{N}$ and down-regulated in both $+\mathrm{N}$ treatments (5,433 genes).

To facilitate the global analysis for each scenario, gene ontology (GO) classification (http://www.geneontology. org) was performed and showed differences in some biological process categories. For instance, we observed that genes involved in the biosynthesis of cell wall main components (lignin, cellulose and hemicelluloses) were differentially expressed between the treatments. For example, some genes of the lignin biosynthetic pathway were up-regulated in the treatment with less nitrogen $(-\mathrm{N})$ and down-regulated in both $+\mathrm{N}$ treatments.

\section{Conclusions}

This first analysis in Eucalyptus allowed us to show an effect of nitrogen fertilization on cell wall composition both at the histological and at the gene expression level. We believe that further experimentscompleted by chemical analysis of wood samples will give more insights in the mechanisms of nitrogen fertilization on wood formation. This knowledge will be important to address new demands on better suited biomass quality for industrial applications.

\section{Author details}

${ }^{1}$ Laboratório de Genômica e Expressão, IB, UNICAMP, Campinas, São Paulo, Brazil. ${ }^{2}$ Génomique Fonctionnelle de l'Eucalyptus, LRSV, UPS/CNRS, CastanetTolosan, France. ${ }^{3}$ Federative Research 3450, Castanet-Tolosan, France.

Published: 13 September 2011

References

1. Pitre FE, Lafarguette F, Boyle B, Pavy N, Caron S, Dallaire N, Poulin PL, Ouellet M, Morency MJ, Wiebe N, Lim EL, Urbain A, Mouille G, Cooke JEK, Mackay JJ: High nitrogen fertilization and stem leaning have overlapping effects on wood formation in poplar but invoke largely distinct molecular pathways. Tree Physiol 2010, 30:1273-1289.

2. Novaes E, Osorio L, Drost DR, Miles BL, Boaventura-Novaes CR, Benedict C, Dervinis C, Yu Q, Sykes R, Davis M, Martin TA, Peter GF, Kirst M: Quantitative genetic analysis of biomass and wood chemistry of Populus under different nitrogen levels. New Phytol 2009, 182:878-890.

3. Li R, Yu C, Li Y, Lam T, Yiu S, Kristiansen K, Wang J: SOAP2: an improved ultrafast tool for short read alignment. Bioinformatics 2009, 25:1966-1967.

4. Wang L, Feng Z, Wang X, Zhang X: DEGseq: an R package for identifying differentially expressed genes from RNA-seq data. Bioinformatics 2010, 26(1):136-138.

doi:10.1186/1753-6561-5-S7-P106

Cite this article as: Camargo et al:: Effects of nitrogen fertilization on global xylem transcript profiling of Eucalyptus urophylla $x$ grandis evaluated by RNA-seq technology. BMC Proceedings 2011 5(Suppl 7):P106.

\section{Submit your next manuscript to BioMed Central} and take full advantage of:

- Convenient online submission

- Thorough peer review

- No space constraints or color figure charges

- Immediate publication on acceptance

- Inclusion in PubMed, CAS, Scopus and Google Scholar

- Research which is freely available for redistribution

Submit your manuscript at www.biomedcentral.com/submit
Ciomed Central 